\title{
The Implementation of the Guiding Principles on Business and Human Rights in Brazil: A Critical Perspective
}

\section{La implementación de los Principios Rectores sobre Empresas y Derechos Humanos en Brasil: Una mirada crítica}

FLÁVIA dO AMARAL ViEIRA ${ }^{1}$

\begin{abstract}
This paper analyses the process of implementing the UN framework of "Protect, Respect and Remedy". First, it presents a historical overview of the UN Guiding Principles on Business and Human Rights, and then it reflects on the repercussions in Brazil, based on the recommendations made after the visit of the UN Working Group in 2015. In 2018, the Brazilian government published a series of regulations, among them, a National Guideline on Human Rights and Business. Unfortunately, the advances contained in the document end up overshadowed by the fact that it was not created in a participatory and transparent way, and by adopting an optional framework when dealing with corporate human rights responsibility, thus mitigating the obligations of respect for human rights by the companies.
\end{abstract}

Keywords: human rights; business; public policies; Brazil.

Resumen: Este artículo analiza el proceso de implementación del documento marco de la ONU "Proteger, Respetar y Remediar". Primero, presenta un panorama sobre los Principios Rectores sobre 
Empresas y Derechos Humanos, y luego reflexiona sobre las repercusiones en Brasil, basándose en las recomendaciones hechas después de la visita del Grupo de Trabajo de la ONU en 2015. En 2018, el gobierno brasileño publicó una serie de regulaciones, entre ellas una Directriz Nacional sobre Derechos Humanos y Empresas. A pesar de algunos avances contenidos en el documento, estos terminan siendo ensombrecidos por el hecho de que no se hizo de manera participativa y transparente, y por haber adoptado un marco optativo en el tratamiento de la responsabilidad empresarial en materia de derechos humanos, mitigando así las obligaciones de respeto de los derechos humanos por parte de las empresas. Brasil.

Palabras clave: derechos humanos; empresas; políticas publicas;

Recibido: 1.10.2020 Aceptado: 20.12.2020

\section{Summary}

\section{Introduction}

2. The UN Agenda on Business and Human Rights

3. The UN Guiding Principles

4. Brazilian National Police on Business and Human Rights: an overview

5. A critical perspective

6. Conclusion

\section{Introduction}

Since 1972, when debates on the development of a Code of Conduct on Transnational Corporations started, the theme of Business and Human Rights has been on the agenda of the United Nations. The speech by the former President of Chile Salvador Allende 
at the United Nations General Assembly of that year, in which he denounced attacks and imperialist actions by transnational corporations to his government and Chilean democracy, is considered an initial milestone in this regard ${ }^{2}$.

The emergence of new forms of accountability of corporations and financial institutions for human rights violations had multiple factors, among them, the strengthening of the international environmental movement, the growing recognition of economic and social rights, and campaigns outside the scope of the United Nations against the destructive potential of large corporation development projects (FEENEY, 2009, p. 175). In this agenda, two perspectives on the theme have been developed: one that defends the need for a binding instrument on human rights for transnational corporationsthrough a treaty that imposed mechanisms of accountability of these actors for violations-and another focused on instruments of voluntary regulation and soft law.

This paper delves into the process of implementing the second perspective, which had as a landmark the publication of the United Nations Guiding Principles for Business and Human Rights in 2011, and the creation of a Working Group on Business and Human Rights (WG), which initiated a mobilization process for national public policies that could bring effectiveness to the document in Brazil.

As a result of the advocacy and incidence of Brazilian civil society at the UN, the country received a visit from the WG in 2015. In 2016, the official report on that visit was published, highlighting crucial issues about the current state of protection of human rights in the context of business activity in Brazil. Since then, this agenda has been inciting debates on what parameters should be applied to a national policy on business and human rights in the country. This process

${ }^{2}$ Salvador Allende's 1972 speech is available at

https://www.marxists.org/archive/allende/1972/december/04.htm 
culminated with the Decree 9571/2018, which establishes the National Guidelines on Business and Human Rights of Brazil.

This is a topic of great importance considering several recent events related to human rights violations by transnational companies in Brazil, among which the ruptures of mining tailings dams in the Rio Doce Basin in 2015 and in Brumadinho ${ }^{4}$, in 2019, both in the state of Minas Gerais. These tragic events exemplify the pattern of human rights violations committed by ETNS and the inefficiency of States and international organizations to hold these companies responsible for violations. Besides, this is a topic little discussed by human rights scholars, both within the country and in the English language, and deserves to be further explored.

To critically analyze the possible advances in terms of public policies on business and human rights in Brazil, I first present an introductory overview of the UN Agenda on Business and Human Rights, to then focus on the nature of the UN Guiding Principles and the National Guidelines for Business and Human Rights in Brazil. Finally, the conclusion reflects on the state of the art of human rights

\footnotetext{
${ }^{3}$ On November 15, 2015, in the sub-district of Bento Rodrigues, $35 \mathrm{~km}$ from MarianaMinas Gerais, the mining tailings dam called "Fundão", controlled by Samarco Mineração SA, a joint venture of the Brazilian company Vale SA and Anglo-Australian BHP Billiton, broke down. The failure of the Fundão dam is considered the industrial disaster that caused the greatest environmental impact in Brazilian history and the largest in the world involving tailings dams, causing 19 deaths. The mud reached the Doce River Basin and the ocean. To learn more, see: MILANEZ, Bruno; LOSEKANN, Cristiana (orgs.). Desastre no Vale do Rio Doce: antecedentes, impactos e açôes sobre a destruicão. Rio de Janeiro: Folio Digital: Letra e Imagem, 2016. Available at: http://www.ufjf.br/poemas/files/2016/06/Milanez-2016-Desastre-no-Vale-do-RioDoce-Web.pdf>

${ }^{4}$ Just over three years after the Samarco/Vale/BHP Billiton disaster in Mariana (MG), in the early afternoon of January 25, 2019, Dam I of the Córrego do Feijão da Vale mine collapsed in Brumadinho (MG). The disruption resulted in a major disaster, with more than 200 dead and about 93 missing, creating a public calamity. The disaster can be considered the second biggest industrial disaster of the century and the biggest work accident in Brazil. To learn more, see: MILANEZ, B. et al. (2019) Minas não há mais: avaliação dos aspectos econômicos e institucionais do desastre da Vale na bacia do rio Paraopeba. Versos - Textos para Discussão PoEMAS, 3(1), 1-114. Available at: http://www.ufjf.br/poemas/files/2017/04/Milanez-2019-Minas-n\%C3\%A3oh\%C3\%Al-mais-versos.pdf>
} 
and business in Brazil, from the perspective of civil society and those affected by human rights violations.

\section{The UN Agenda on Business and Human Rights}

Until now, the regulations adopted by international organizations on business and human rights were only codes of conduct, in the sense that their application depended on the goodwill of states and transnational companies, with no possibility of sanction for non-compliance. The scope of corporate responsibility concerning human rights occurs in at least five areas: labor law, global value chains (which involves protecting the communities and victims affected by business activity), to the State, and extraterritorial liability (regarding the risks of violation in other countries).

In chronological order, the main specific rules applicable to transnational companies are the Guidelines for Multinational Enterprises of the Organisation for Economic Co-operation and Development (1976), the Tripartite Declaration of Principles concerning Multinational Enterprises, and Social policy of the Organization International Labor Organization (1977), the UN Global Compact (2000) and the UN Guiding Principles on Business and Human Rights (2011). I will focus my analysis on the UN Guiding Principles, because it is considered to have the greatest impact on the activity so far.

Adopted by the United Nations Human Rights Council, the Guiding Principles on Business and Human Rights offers global parameters to prevent and address negative impacts on human rights related to business activities. In 2011, the Working Group on the issue of human rights and transnational corporations and other business enterprises (also referred to as the Working Group on Business and Human Rights) was created. It is made up of experts from different 
countries $^{5}$, whose mandate includes the development of the implementation of the Guiding Principles by member states.

The principles were created based on the work of John Ruggie, who was appointed in 2005 as Special Representative of the SecretaryGeneral on human rights and transnational corporations and other business enterprises (SRSG) by the then UN Human Rights Commission. In 2008, Ruggie presented a report recognizing that the expansion of markets and the transnational reach of business activity did not coincide with an equal expansion of the protection of individuals and communities against human rights violations that involved companies (UNITED NATIONS, 2007).

This report, the UN “Protect, Respect and Remedy” Framework, consists of three parts, which in essence state the following: First, States must protect against human rights violations committed by third parties, including corporations, through policies, standards, as well as adequate legal proceedings. Second, corporations have a responsibility to respect human rights standards, which, according to the SRSG, essentially involves controlling the risks of causing damage to human rights, seeking, in the last instance, to avoid such damages. Lastly, human rights victims must have greater access to effective remedies, including non-judicial reporting mechanisms (UNITED NATIONS, 2008).

Approved by Resolution A/HRC/RES/8/7, this broad normative framework presented by Ruggie was well received by business associations, governments, and many civil society organizations. Thus, their mandate was extended for another three years, with the mission of operationalizing the presented framework, a process that gave birth to the Guiding Principles on Human Rights and Business.

\footnotetext{
${ }^{5}$ In 2020, the Working Group is composed of Elżbieta Karska (Poland), Dante Pesce (Chile), Anita Ramasastry (United States), Githu Muigai (Kenya), and Surya Deva (India). See more at

http://www.ohchr.org/EN/Issues/Business/Pages/Members.aspx.
} 


\section{The UN Guiding Principles on Business and Human Rights}

The Guiding Principles follow the three pillars of "protect, respect and remedy". To comply with the duty of protection, among other obligations, States have to enforce laws whose object or effect is to ensure that companies respect human rights, including periodically assessing whether these laws remain adequate, remedying any deficiencies, and advising companies on how to respect human rights in their activities.

As for the duty to respect, corporations must refrain from violating human rights and deal with the negative consequences of the activities in which they have some involvement-due diligenceto ensure that their activities and relationships do not violate human rights. The Guiding Principles clearly state that this responsibility extends to all business operations and relationships, regardless of what the State does or does not do. Furthermore, they prescribe that corporate responsibility refers to internationally recognized human rights, understood, at a minimum, as those expressed in the International Bill of Human Rights as well as the principles concerning fundamental rights set out in the International Labor Organization's Declaration on Fundamental Principles and Rights at Work.

Finally, with regard to mechanisms of reparation and access to justice, the principles provide that, as part of their duty to protect against human rights violations related to business activities, States must take appropriate measures to ensure, through judicial, administrative, legislative or any other corresponding means that, when such abuses occur in their territory or jurisdiction, those affected can access effective mechanisms for remedy. In addition, corporations must ensure that effective grievance/ complaint mechanisms are available. 
One of the main criticisms of these Principles is that they fail to impose an express obligation of protection by non-state entities, new obligations under international law, or a new conceptual framework. Instead, they are "political commitments" made by states within the United Nations on guidelines, recommendations, and standards for responsible business conduct. These provisions have in common that they intend to require corporations to respect social and environmental standards.

In the first annual report to the Human Rights Council, the Working Group on Business and Human Rights recommended that each country should draw up a National Action Plan (NAP) as part of the process of implementing the Guiding Principles. In 2016, the Group developed a Guiding Document ${ }^{6}$ to help them achieve this goal.

NAPs can be defined as a political strategy developed by the state to protect against adverse impacts to human rights caused by corporations, in accordance with the Guiding Principles. They can be understood as a tool for mapping obstacles and good practices in order to fulfill obligations in a consistent manner. Since 2013, at least 20 countries have launched their respective plans 7 . A key policy of the WG's activities, the plans focus on the relationship between the state and human rights and maintain the guidelines in a general abstract plan. Thus, the risk is that they will be embodied in innocuous political documents, which only internationally legitimize states that violate human rights, without changes in the national and local scenarios. This will perpetuate impunity in the international sphere, since transnational enterprises will continue to use the societal and

\footnotetext{
${ }^{6}$ Available at:

http://www.ohchr.org/Documents/Issues/Business/UNWG NAPGuidance.pdf 7 They are Ireland (2017), Czech Republic (2017), France (2017), Poland (2017), Spain (2017), Belgium (2017), Chile (2017), United Kingdom (launched in 2013, updated in 2016), Switzerland (2016), Italy (2016), United States (2016), Germany (2016),

Lithuania (2015), Sweden (2015), Norway (2015), Colombia (2015), Denmark (2014), Finland (2014), and Holland (2013). For follow-up,

see:<http://www.ohchr.org/EN/Issues/Business/Pages/NationalActionPlans.aspx>
} 
jurisdictional fragmentation that allows them to evade human rights obligations.

Despite these shortcomings, there is a potential to transform national normative frameworks for the protection of human rights, as well as to open space for social transformations capable of improving citizens' living conditions. The implementation of the plans may represent an advance in the human rights and business agenda regarding human rights violations committed by companies operating within a state.

To face this challenge, the NAPs elaborating process should be conducted in a transparent and participatory way-one that promotes the inclusion of the theme of human rights and business in national politics. In the next section, I will analyze how Brazil has developed its national policy on human rights and business.

\section{Brazilian National Policy on Business and Human Rights: an overview}

In December 2015, the Business and Human Rights Working Group carried out a visit to Brazil. The mission aimed to evaluate the prevention of negative impacts of business activities on human rights in seven cities: São Paulo, Rio de Janeiro, Belo Horizonte, Mariana, Altamira, Belém, and Recife.

In June 2016, the mission report was presented during the $36^{\text {th }}$ regular session of the UN Human Rights Council. The Group documented crucial issues about the current state of protection of human rights in Brazil, especially regarding large infrastructure projects, such as the Belo Monte Dam, agribusiness, and megaevents. The WG pointed to structural problems in the environmental licensing processes for these projects. It also expressed concern about the promiscuous relationship between private capital and public authorities in the country, criticizing the high degree of influence that large corporations have in the decision-making process and in the 
formulation of laws, regulations, and public policies. Plus, the state is in an ambivalent position, as it functions as the main financier of such projects through the state development bank, BNDES.

Among the conclusions, we find that (a) Brazil seeks development at the expense of human rights, (b) corporations do "business as usual", (c) affected communities are systematically ignored, and (d) there are risks of regression in the legal framework. Despite the relevant criticisms made by the WG, the report focuses mainly on the state: of the 32 recommendations made in the text, only 7 are aimed at corporations (HOMA, 2016).

Based on the Guiding Principles, the Group also recommended the development of a NAP on business and human rights and the definition of clear policies for enterprises in the country that respect human rights. In addition, it highlighted the importance of dialogue between the multiple stakeholders in the construction of rules to guarantee the observance of human rights by companies, in order to include the voices of the affected communities and human rights defenders in the process.

After the visit, the business and human rights agenda at the national level started to be managed by the Ministry of Women, Family and Human Rights, which conducted a consultation to guide the implementation of the recommendations. According to the Ministry, more than 130 actors, including federal agencies, corporations, and civil society, were consulted to collect information about the initiative on the responsibility of these institutions in line with the UN recommendations $(\mathrm{MDH}, 2018)$. Although the spectrum of entities consulted appears to be broad, there was no public consultation on the construction of the document responding to the recommendations. The criteria for selecting the entities that were consulted were not disclosed (CONECTAS, 2019, pg. 29).

In the meantime, several Brazilian civil society groups have been devoting themselves to the human rights and business agenda in the last decade-members of the academia, NGOs, social movements, 
associations representing the interests of those affected by human rights violations, and the press, among others.

These groups have even actively participating in meetings and events related to the theme in Geneva, at the United Nations headquarters, both in the Forum on Business and Human Rights, organized by the WG, and in the sessions of the Open-ended intergovernmental Working Group on transnational corporations and other business enterprises concerning human rights (OEIGWG) (this UN group coordinates the work for a binding treaty on the subject ${ }^{8}$; however, I will not delve into this subject for reasons of space). For example, the Global Campaign to Reclaim Peoples Sovereignty, Dismantle Corporate Power and Stop Impunity, an extensive network of social movements, civil society organizations (CSOs), trade unions and communities, counts with the participation of at least fourteen Brazilian organizations ${ }^{9}$.

Roland et al. (2018, p. 46) explain that the creation of the OEIGWG is an important milestone for Brazilian civil society, which has since intensified its work through advocacy and disseminating information on the issue. In 2017, the pressure from civil society for the democratic and participatory construction of a policy that establishes binding norms capable of holding companies directly responsible for human rights violations had a positive outcome. The Federal Attorney for Citizens' Rights (Procuradoria Federal dos Direitos do Cidadão) (PFDC), an organ of the Federal Prosecution Office (Ministério Público Federal) (MPF), decided to hold a national public hearing to promote a dialogue with civil society, mainly with those affected by the business activity, about appropriate public policies on human rights and corporations (SENRA, 2019, p. 169).

\footnotetext{
${ }^{8}$ More information at: https://www.ohchr.org/EN/HRBodies/HRC/WGTransCorp/Pages/IGWGOnTNC. aspx>.

${ }^{9}$ More information at: https://www.stopcorporateimpunity.org/call-to-internationalaction/>
} 
However, in November 2018, these groups were surprised by the publication of Decree No. 9571, which establishes the National Guidelines on Business and Human Rights ${ }^{10}$ (Diretrizes Nacionais sobre Empresas e Direitos Humanos) for medium and large companies, including multinational companies operating in the country. The document sets out rules with regard to the state's obligations to protect human rights in relation to business activities; corporate responsibility with respect for human rights; access to repair and remediation mechanisms; and its process of implementation, monitoring, and evaluation.

The Decree takes the Guiding Principles as a paradigm; consequently, it is optional for companies to comply with it. The regulation establishes the duty of the State to develop public policies and changes in the legal system to consider the impact of companies in the entire supply chain, as well as to encourage the creation of measures that guarantee reparations in favor of groups in situations of vulnerability. Concerning social transparency mechanisms, the Decree recommends that corporations should adopt a code of conduct, and report clearly, transparently, and loyally on the risks of their operations and measures adopted to prevent them. Once again, the relationship between the state and companies does not seem very clear. The question remains whether it is up to the state to impose these constraints on companies, as well as what the real viability of carrying out such a task.

In line with this approach, the Decree comprises a series of relevant obligations that the Brazilian state must fullfil. Thus, for example, it provides for the training of public servants to deal with human rights violations in a business context; the improvement of social participation mechanisms; the creation of programs to encourage the hiring of vulnerable groups, to combat child labor and slavery; the guarantee of technical support to vulnerable groups in

${ }^{10}$ Available at (in Portuguese): http://www.planalto.gov.br/ccivil_03/_ato20152018/2018/Decreto/D9571.htm 
their negotiations with corporations; the improvement of inspection mechanisms; the creation of a Monitoring Committee for the National Guidelines on Business and Human Rights, among other measures.

During 2018, several regulations on business and human rights were issued by the Brazilian government. In addition to the mentioned Decree, a Code of Conduct and Respect for Human Rights for Suppliers of Goods and Services of the Ministry of Human Rights ${ }^{11}$ (Código de Conduta e de Respeito aos Direitos Humanos para Fornecedores de Bens e de Serviços do Ministério dos Direitos Humanos), Ordinance 350, of November 20, 2018, was released in order to clarify the minimum conduct in terms of ethics, sustainability and respect for human rights that was expected from all companies with which the Ministry has partnerships and contracts.

The Ministry also adopted an Open Charter for Business Enterprises for Human Rights, a commitment signed by the Brazilian state and companies that would be in favor of the protection of human rights. Plus, the Business and Human Rights Committee was established by Ordinance No. 289, of August 10, 2018, as an incentive for practices that guarantee human rights within the institution, such as the inclusion of groups that face social vulnerability, accessibility, and equal opportunities.

These promising regulations ended up being overshadowed by the fact that they were created in a non-participatory manner, and because of the adoption of an optional framework when dealing with corporate human rights responsibility. States, both according to the Guiding Principles and the Decree of the Brazilian Government, remain as the main responsible for protecting human rights. It is up to them, regardless of their weaknesses and the constraints of international global capital, to ensure that corporations respect human rights (HOMA, 2018, p. 05).

\footnotetext{
${ }_{11}$ Available at: https://www.in.gov.br/materia//asset_publisher/Kujrw0TZC2Mb/content/id/51057848/do1-2018-11-21-portaria-n350-de-20-de-novembro-de-2018-51057742
} 
This perspective ignores that the Brazilian reality is complex. Research carried out by the Latin American Post-Graduate Consortium in Human Rights on the regulation policies of transnational corporations in Brazil pointed out several problems regarding the compliance of human rights by these companies today. Among those issues, there is the presence of work analogous to slavery and child labor; deficits in access to justice and information; and violations of the right to freedom of association. Further compromising this scenario, the research has shown serious problems of institutional articulation in overseeing and combating these practices ${ }^{12}$.

\section{A critical perspective}

As presented in the previous section, the Brazilian National Policy on Business and Human Rights has serious weaknesses that call into question its capacity to regulate business activity in relation to human rights. Firstly, it is noteworthy that in the process of drafting and publishing the National Guidelines, there was no transparency or consultation with civil society and those affected by human rights violations committed by corporations. Furthermore, as mentioned, the Brazilian government ignored an entire debate already underway in Brazilian society.

Among civil society groups, the role of the GT Corporations should be highlighted. This a group organized by various nongovernmental organizations, social movements, and academics that since 2014 have been holding meetings, seminars, and developing reflections on the state of the art of human rights and business in Brazil. For example, this group played an important role in holding the first Brazilian Public Hearing on Business and Human Rights, in

\footnotetext{
${ }^{12}$ See "Políticas de Regulação de Empresas Transnacionais por violações de Direitos Humanos - Diagnósticos nacionais. MAUÉS, Antônio Moreira; et al. (Orgs.). Ed. CEGRAF-UFG, 2018. Available at:

https://www.cegraf.ufg.br/up/688/o/ebook_diagnosticos_nacionais.pdf>
} 
2017, and on the second Seminar Balance of the Rio Doce disaster, at the Federal University of Espírito Santo (UFES). Also active in this debate is the PFDC, which in 2018 created an internal working group on Business and Human Rights.

In August 2018, the PFDC published a Technical Note entitled "The protection and repair of human rights in relation to business activities" ${ }^{13}$. The Note proposes a reinforcement of the national and international regulatory system so that transnational companies are constrained to adopt the same standard of protection for human rights in all countries and communities in which they operate, directly or indirectly, highlighting the need implementation of public policies aimed at respecting and protecting human rights.

The debate was ongoing, in a context in which Brazilian civil society was qualified to face the issue. This seems to have been underestimated or ignored at the time of the elaboration of the Government Decree, which in addition does not comply with the guidelines for the processes of drafting human rights standards (HOMA, 2018, p. 07).

The content of the National Guidelines was not subjected to public consultation. The Government did not publish a preliminary version of the text of the decree, nor it called for civil society to make contributions. Thus, there was no possibility for people and communities affected or potentially affected by the activities of corporations to participate in the creation process (CONECTAS, 2019). Consequently, several topics covered by the National Guidelines do not correspond to the advancement of the debate and the complexity of the discussion that was ongoing within civil society, both nationally and internationally, on the theme of business and human rights.

\footnotetext{
${ }^{13}$ Available at: http://pfdc.pgr.mpf.mp.br/temas-de-atuacao/notas-tecnicas/notatecnica-pfdc-7-2018
} 
Another issue is the voluntary implementation of the rules on behalf of businesses. The Decree establishes that the companies' responsibilities provided for in the Guidelines are voluntary, thus mitigating the obligations of respect for human rights (Art. 1, $\$ 2$ ). The voluntary framework of the decree can also be appreciated in the provision that deals with the creation of a "Business and Human Rights" seal, intended for companies that decide to implement the Guidelines (Art. 1, $\S 3$ ). Thus, there is an award for companies for the simple act of fulfilling their human rights obligations. In the meantime, the Decree does not provide for the possibility of revoking the seal in the event of retrogression in the implementation of the Guidelines.

The roots of this problem are found in the way the UN responded to the demand for mechanisms to hold transnational companies accountable for human rights violations, since it is an organization that depends on contributions from those same companies. John Ruggie, the SRSG, in addition to being a Harvard professor, was also a business consultant, and had already participated in the writing of the Global Compact in 1999. His appointment ensured the elaboration of a document compatible with business aspirations and little "threatening" to the logic of their investments (HOMA, 2018, p. 05).

It is not for nothing that States, in the translation and interpretation of the Guiding Principles, remain as the main responsible for protecting Human Rights, and it is up to them, regardless of their weaknesses and the conditions of international global capital, to ensure that companies respect Human Rights; describing the role of companies as entities with a natural vocation for the collective good, guided by the logic and almost rational and neutral rationality of "development," which, at most, would present "risks" that should be borne for the advancement of societies where the ventures would be installed (HOMA, 2018, p. 05). 
In this sense, the fact that the Principles are of voluntary compliance is not the only problem. The most serious one is the whole logical framework that is established in them and the consequences of their language, which can even function as a positive marketing business. For example, if we analyze the Brazilian case, at the same time that the state has published a series of regulations on this matter, in practice it has acted in the opposite direction, weakening the institutions that provide technical support to historically vulnerable groups (such as the National Indian Foundation), as well as labor legislation and mechanisms of social participation ${ }^{14}$.

These measures are a mark of the return to power of right-wing governments in Brazil in 2016, supported by agribusiness entrepreneurs and transnational mining corporations. They have an openly anti-indigenous discourse, contrary to human rights and in favor of eliminating environmental protection, never before seen in the history of democratic Brazil. Since then, the risk conditions for the survival of traditional peoples and environmental resources have intensified, precisely on a planet threatened by climate change and health crises. The neoliberal agenda that calls for the release of pesticides, the dismantling of environmental oversight, the questioning of deforestation data, and the strengthening of the discourse that environmental issues should be made more flexible for economic development, is a key characteristic of the Brazilian current government.

By denying that there are binding human rights obligations for companies, the progress in international human rights law is reversed, instead of more effectively incorporating the appropriate treatment of an already consolidated issue (HOMA, 2018, p.13). The main challenge is to channel business logic to be in accordance with human rights guidelines, and not the other way around. The Decree

\footnotetext{
${ }^{14}$ See Inter-American Commission on Human Rights. Situação dos direitos humanos no Brasil. Aprovado pela Comissão Interamericana de Direitos Humanos em 12 de fevereiro de 2021. Available at:

http://www.oas.org/pt/cidh/relatorios/pdfs/Brasil2021-pt.pdf>
} 
9.571 does not clearly establish the supremacy of human rights over trade and investment agreements, or any business venture project. In this sense, it seems that the international protection of human rights still depends on the goodwill of corporations.

\section{Conclusion}

For more than four decades, the topic of business and human rights has been on the United Nations agenda. This paper has anaysed the process of implementing the UN framework of "Protect, Respect and Remedy," first presenting a historical overview of the UN Guiding Principles, and then reflecting on their repercussions in Brazil.

The Working Group mission in 2015 aimed to evaluate the prevention of negative impacts of business activities on human rights, and in doing so, it documented crucial issues about the current state of protection of human rights in Brazil, especially regarding large infrastructure projects, such as the Belo Monte Dam, agribusiness and mega-events.

Several Brazilian civil society groups have been devoting themselves to the human rights and business agenda in the last decade-members of the academia, NGOs, social movements, associations representing the interests of those affected by human rights violations, and the press, among others. However, in November 2018, these groups were surprised by the publication of Decree No. 9571, which establishes the National Guidelines on Business and Human Rights for medium and large companies, including multinational companies operating in the country. The document sets out rules with regard to the state's obligations to protect human rights in relation to business activities; corporate responsibility with respect for human rights; access to repair and remediation mechanisms; and its process of implementation, monitoring, and evaluation. 
On the balance sheet, some promising regulations ended up being overshadowed by the fact that they were created in a nonparticipatory manner, and because of the adoption of an optional framework when dealing with corporate human rights responsibility.

Another issue is the voluntary implementation of the rules on behalf of businesses. However, the fact that the Principles are of voluntary compliance is not the only problem. The most serious one is the whole logical framework that is established in them and the consequences of their language, which can even function as a positive marketing business. In Brazil, at the same time that the state has published a series of regulations on this matter, in practice it has acted in the opposite direction. The main challenge is to channel business logic to be in accordance with human rights guidelines, and not the other way around. In this sense, it seems that the international protection of human rights still depends on the goodwill of corporations.

\section{References}

CONECTAS. (2019). Segundo relatório de acompanhamento das recomendaçôes ao Brasil do grupo de trabalho da ONU sobre empresas e direitos humanos. São Paulo, Brasil. Disponível em: https://www.conectas.org/publicacoes/download/2o-relatoriode-acompanhamento-das-recomendacoes-ao-brasil-do-gt-daonu-sobre-empresas-e-direitos-humanos>

Deva, S. and Bilchitz, D. (2013). Human Rights Obligations of Business. In Deva, S., and Bilchitz, D., Human Rights Obligations of Business: Beyond the Corporate Responsibility to Respect? Cambridge: Cambridge University Press.

Feeney, Patricia. (2009). A luta por responsabilidade das empresas no âmbito das nações unidas e o futuro da agenda de advocacy. Sur. Revista Internacional de Direitos Humanos, 6(11), 174-191. https://doi.org/10.1590/S1806-64452009000200009

Hobeika, Monica Defilippi. (2020). As recentes ações do Brasil sobre direitos humanos e empresas se afastam das diretrizes 
internacionais eficazes sobre o assunto. In RUBIO, David Sanchez et al, Derechos humanos desde la interdisciplinariedad en ciencias sociales y humanidades. DYKINSON. Madrid.

HOMA-Centro de Direitos Humanos e Empresas. (2016). Grupo de Trabalho da ONU sobre direitos humanos e empresas: HOMA divulga análise do relatório da visita ao Brasil e lança campanha pelo tratado vinculante.: http://homacdhe.com/index.php/pt/2016/06/29/grupo-detrabalho-da-onu-sobre-direitos-humanos-e-empresas-homadivulga-analise-do-relatorio-da-visita-ao-brasil-e-lancacampanha-pelo-tratado-vinculante/

2018. Reflexões sobre o Decreto 9571/2018 que estabelece Diretrizes Nacionais sobre empresas e Direitos Humanos.In. Cadernos de Pesquisa Homa. vol. 1, n. 7 .

MDH - Ministério da Mulher, Família e de Direitos Humanos: https://www.mdh.gov.br/todas-asnoticias/2018/novembro/mdh-aprimora-instrumentos-parareforcar-agenda-empresas-e-direitos-humanos

Netto Junior, Edmundo Antonio Dias; Weichert, Marlon Alberto; Nunes, Raquel Portugal. (2019). A desconstrução do caráter vinculante das normas sobre empresas e direitos humanos: da natureza voluntária dos princípios Ruggie à voluntariedade das diretrizes nacionais. Homa Publica - Revista Internacional De Direitos Humanos E Empresas 3 (2), e:046. https://periodicos.ufjf.br/index.php/HOMA/article/view/30581

Oliveira, Carina; Vieira, Flávia do Amaral et al. (2018). Manual sobre Direitos Humanos e Empresas Transnacionais na América Latina. UFG: Goiânia.

Roland, Manoela Carneiro et al. Planos Nacionais de Ação sobre direitos humanos e empresas: inputs para a realidade brasileira. Parte I: Perspectivas gerais sobre os planos nacionais de ação sobre empresas e direitos humanos. Homa- Centro de Direitos Humanos e Empresas, 2016. Acess in http://homacdhe.com/wpcontent/uploads/2016/01/Perspectivas-Gerais-sobre-osPlanos-Nacionais-de-Ac\%CC\%A7a\%CC\%83o-sobre-Empresase-Direitos-Humanos.pdf> empresas e direitos humanos na América Latina: análises sobre 
Colômbia, México e Chile. In: ROLAND, Manoela (coord.). Cadernos de pesquisa Homa, Juiz de Fora, v. 1, n. 4, p.1-60, 2018. Disponível em: http://homacdhe.com/wpcontent/uploads/2018/08/Caderno-de-Pesquisa-Homa-PlanosNacionais-de-Ação.pdf>

Senra, L. M. (2019). Reflexões a partir da audiência pública "Direitos Humanos e empresas: qual é a política pública que o Brasil precisa?". Homa Publica - Revista Internacional De Derechos Humanos $Y$ Empresas, 3(2), e:051. Recuperado a partir de https://periodicos.ufjf.br/index.php/HOMA/article/view/30586

United Nations, (2005). Commission on Human Rights. Human rights and transnational corporations and other business enterprises. U.N.NN Doc. E/CN.4/RES/2005/69. 20 AprApril 20. Available at $<$ http://ap.ohchr.org/documents/E/CHR/resolutions/E-CN_4RES-2005-69.doc $>$.

(2007). Human Rights Council. Business and Human Rights: Mapping International Standards of Responsibility and Accountability for Corporate Acts. U.N.NN Doc. A/HRC/4/035. Available at: <http://www.businesshumanrights.org/Documents/RESG-report-Human-RightsCouncil-19-Feb-2007.pdf>

(2008). Human Rights Council. Protect, Respect and Remedy: A Framework for Business and Human Rights, Report of the Special Representative of the Secretary-General on the issue of human rights and transnational corporations and other business enterprises, John Ruggie. U.N.NN Doc. A/HRC/8/5. 7 AprApril 7. Available at:

$<$ http://www.reports-and-materials.org/Ruggie-report-7-Apr2008.pdf>.

Working Group on Business and Human Rights. (2016). Report of the Working Group on the issue of human rights and transnational corporations and other business enterprises on its mission to Brazil. Available at: https://ap.ohchr.org/documents/dpage_e.aspx?si=A/HRC/32/4 5/Add.1 